\title{
Assessment of Undiscovered Oil and Gas Resources of the Sud Province, North-Central Africa
}

The Sud Province located in north-central Africa recently was assessed for undiscovered, technically recoverable oil, natural gas, and natural gas liquids resources as part of the U.S. Geological Survey's (USGS) World Oil and Gas Assessment. Using a geology-based assessment methodology, the USGS estimated mean volumes of 7.31 billion barrels of oil, 13.42 trillion cubic feet of natural gas, and 353 million barrels of natural gas liquids.

\section{Introduction}

The main objective of the U.S. Geological Survey's (USGS) World Petroleum Resources Project is to assess the potential for undiscovered, technically recoverable oil and natural gas resources of the world, exclusive of the United States. As part of this program, the USGS recently completed an assessment of the Sud Province (fig. 1), an area of approximately 978,800 square kilometers $\left(\mathrm{km}^{2}\right)$ that covers parts of the Central African Republic, Chad, Ethiopia, Camaroon, and Sudan. This assessment was based on data from oil and gas wells and fields, field production records, and published geologic reports. At the time of the assessment, the province contained 113 oil fields - 18 in Chad and 95 in Sudanand was considered to be underexplored for its size. There was one gas field in the province but several discoveries reported associated gas in oil fields. The producing oil fields and recent petroleum discoveries were limited to the Cretaceous-Tertiary rift basins.

The Sud Province was assessed for the first time because of increased exploratory activity and interest in its future potential for energy resources. The assessment was geology-based and used the total petroleum system (TPS) concept. The geologic elements of a TPS include hydrocarbon source rocks (source rock maturation and hydrocarbon generation and migration), reservoir rocks (quality and distribution), and traps for hydrocarbon accumulation. Using

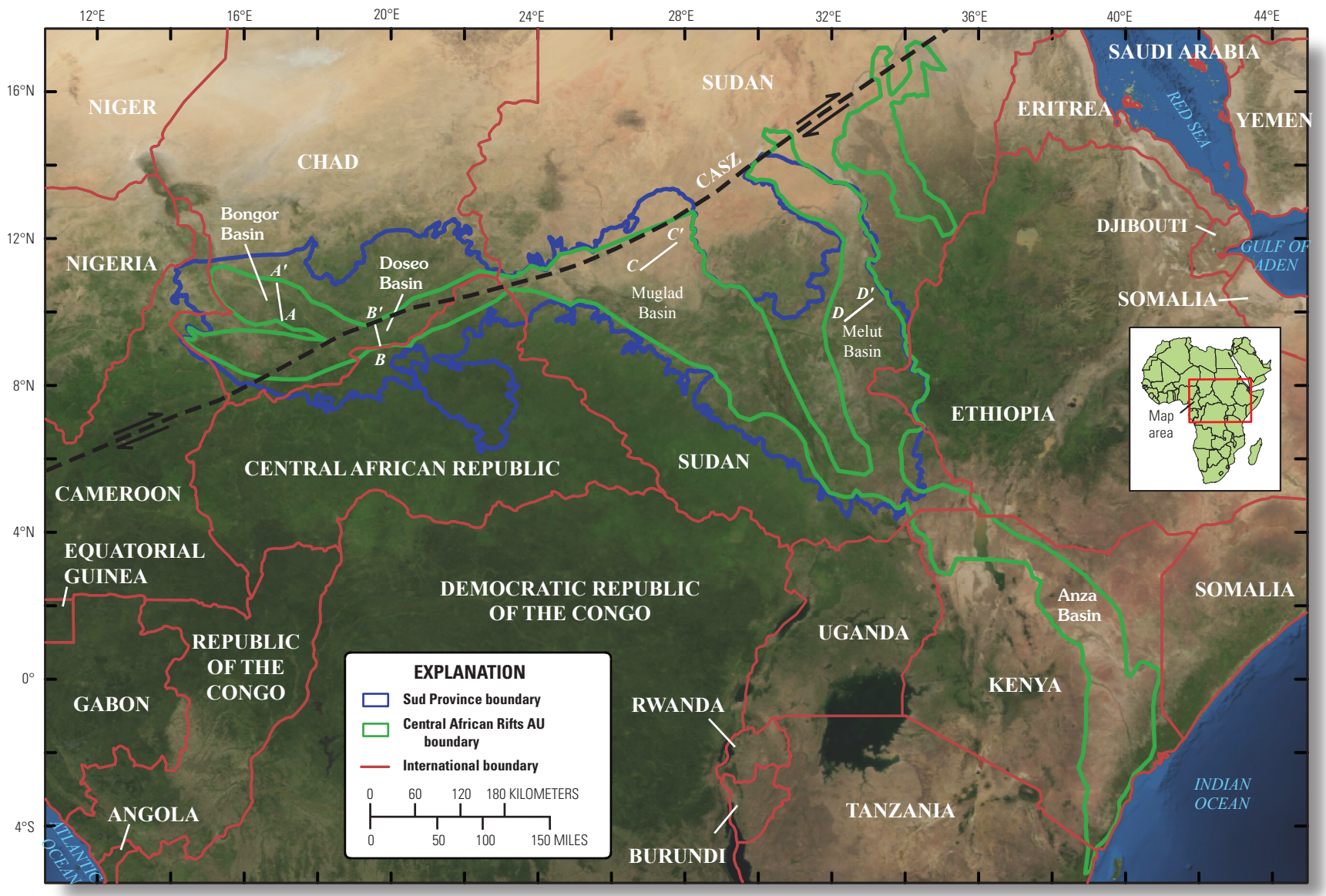

Figure 1. Locations of the Sud Province, Central African Rifts Assessment Unit (AU), and approximate locations of cross sections shown in figures 2 and 4 . CASZ, Central African shear zone. 
these geologic criteria, the USGS defined the Cretaceous-Cenozoic Composite Total Petroleum System (TPS) with one assessment unit (AU), the Central African Rifts AU (fig. 1), encompassing about $848,825 \mathrm{~km}^{2}$, that extends beyond the Sud Province boundary. The AU includes parts of the Central African Republic, Chad, Ethiopia, Kenya, Sudan, and Tanzania (fig. 1). The TPS was defined to include Cretaceous and Paleogene lacustrine and marine source rocks and the AU contains Cretaceous and Paleogene clastic reservoirs, shale seals, and traps that mostly are associated structurally with extensional and transtensional faulting and minor compressional inversion.

The Central African Rift system was initiated during the Early Cretaceous, during the opening of the south Atlantic and the commencement of regional northwest-southeast extension. The rifting continued into the Neogene and can be divided into two rifting events in the western part and three rifting events in the eastern part. The rift basins of central Africa are linked along the Central African shear zone (CASZ) right-lateral fault system (fig. 1). Several thousand meters of Lower Cretaceous clastic sediments, mostly lacustrine clays, silts, and sands, were deposited during this rifting phase (Genik, 1992, 1993).

The Cretaceous-Tertiary rift basins of the western part of the Sud Province (fig. 1) are extensional and transtensional and are filled with Lower Cretaceous to Neogene sedimentary rocks, ranging in thickness from about 3,000 meters (m) to more than 7,500 m (fig. 2) that were deposited in fluvial and lacustrine environments (Genik, 1992; 1993). During the Early Cretaceous, the first rifting phase occurred and fluvial and lacustrine sediments were deposited in the rift basins of southern Chad and the Central African Republic (fig. 2). In the Late Cretaceous (Cenomanian to Turonian) there was a regional rifting event that deposited thick continental clastic sediments. During the Late Cretaceous and Paleogene, transtensional faulting and sag events occurred in the western part of the Sud Province and fluvial and lacustrine sediments were deposited.
The rift basins in the eastern part of the province are extensional and transtensional and filled with Lower Cretaceous to Neogene sedimentary rocks, ranging in thickness from $6,000 \mathrm{~m}$ to more than $13,000 \mathrm{~m}$ that were deposited in fluvial and lacustrine environments (Mohamed and others, 2000, 2002; Dou and others, 2007). The initial rifting event began in the latest Jurassic and continued through the Early Cretaceous (fig. 3), resulting in the deposition of Lower Cretaceous lacustrine source sediments (figs. 3, 4). The second rifting event began in the Turonian and continued into the Senonian, and the third stage of rifting occurred during the Paleogene, contemporaneous with the commencement of the Red Sea rifting (Mohamed and others, 2000). Each rifting event was followed by a sag event, during which thick continental clastic sediments were deposited (fig. 3).

The central African rift basins are known to contain Cretaceous to Paleogene lacustrine and marine source rocks that have generated hydrocarbons since the Late Cretaceous (Genik, 1992, 1993; Mohamed and others, 2002). The generated hydrocarbons migrated into Cretaceous and Paleogene reservoirs and structural traps.

\section{Resource Summary}

Using a geology-based assessment, the USGS estimated mean volumes of undiscovered, technically recoverable conventional oil and gas resources for the Central African Rifts AU in the Sud Province (table 1). The mean volumes are estimated at 7,310 million barrels of oil (MMBO), 13,418 billion cubic feet of gas (BCFG), and 353 million barrels of natural gas liquids. The estimated mean size of the largest oil field that is expected to be discovered is 1,112 $\mathrm{MMBO}$, and the estimated mean size of the expected largest gas field is 3,677 BCFG. A minimum undiscovered field size of 1 million barrels of oil equivalent (MMBOE) was used for this assessment. No attempt was made to estimate economically recoverable reserves.
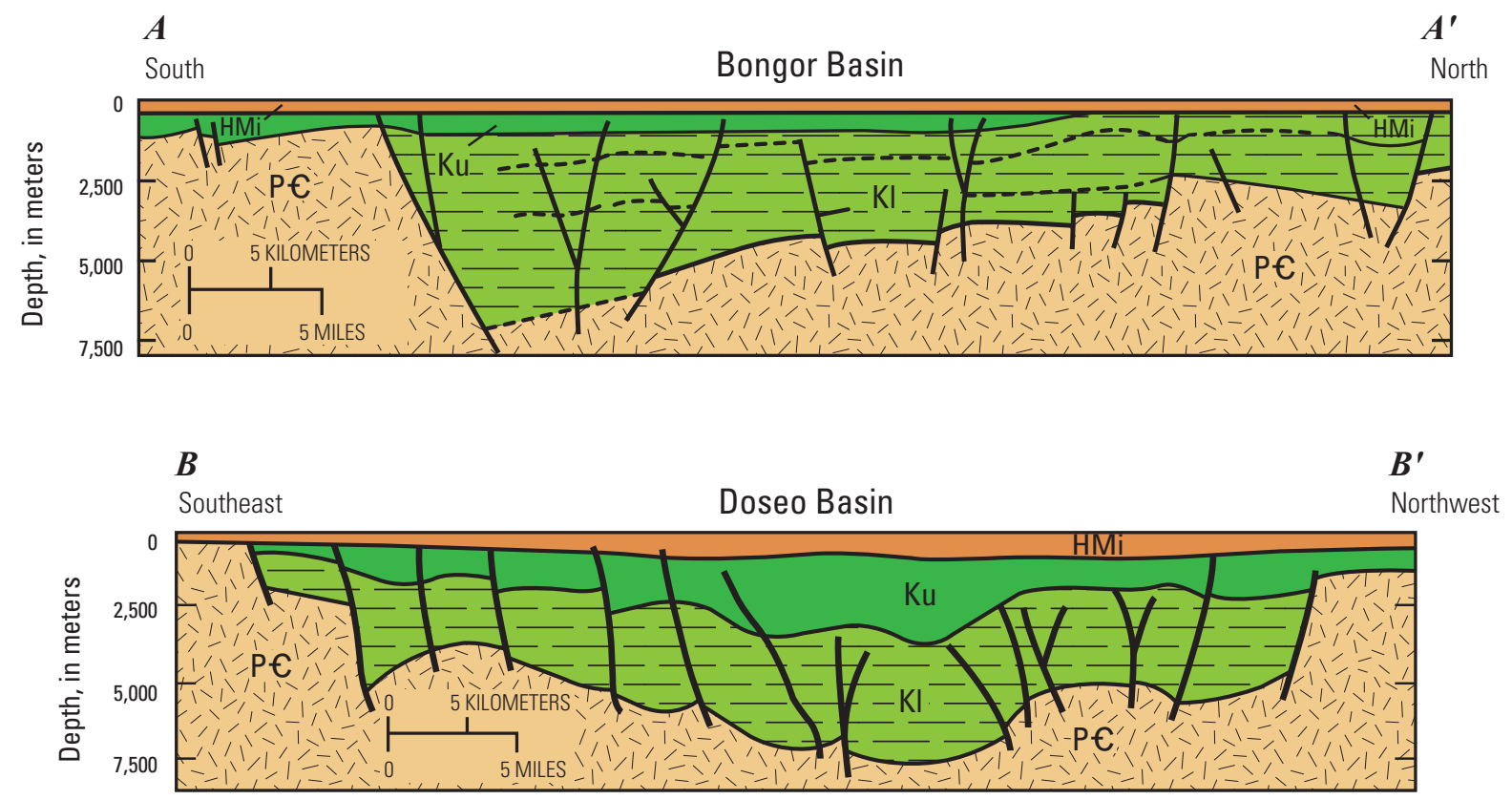

Figure 2. Schematic geologic cross sections of the western part of the Bongor and Doseo Basins showing sedimentary fill in the western part of the Sud Province, north-central Africa. Location of cross sections shown in figure 1. P€, Precambrian; KI, Lower Cretaceous; Ku, Upper Cretaceous; HMi, Holocene to Miocene. Modified after Genik (1992). 
Muglad Basin

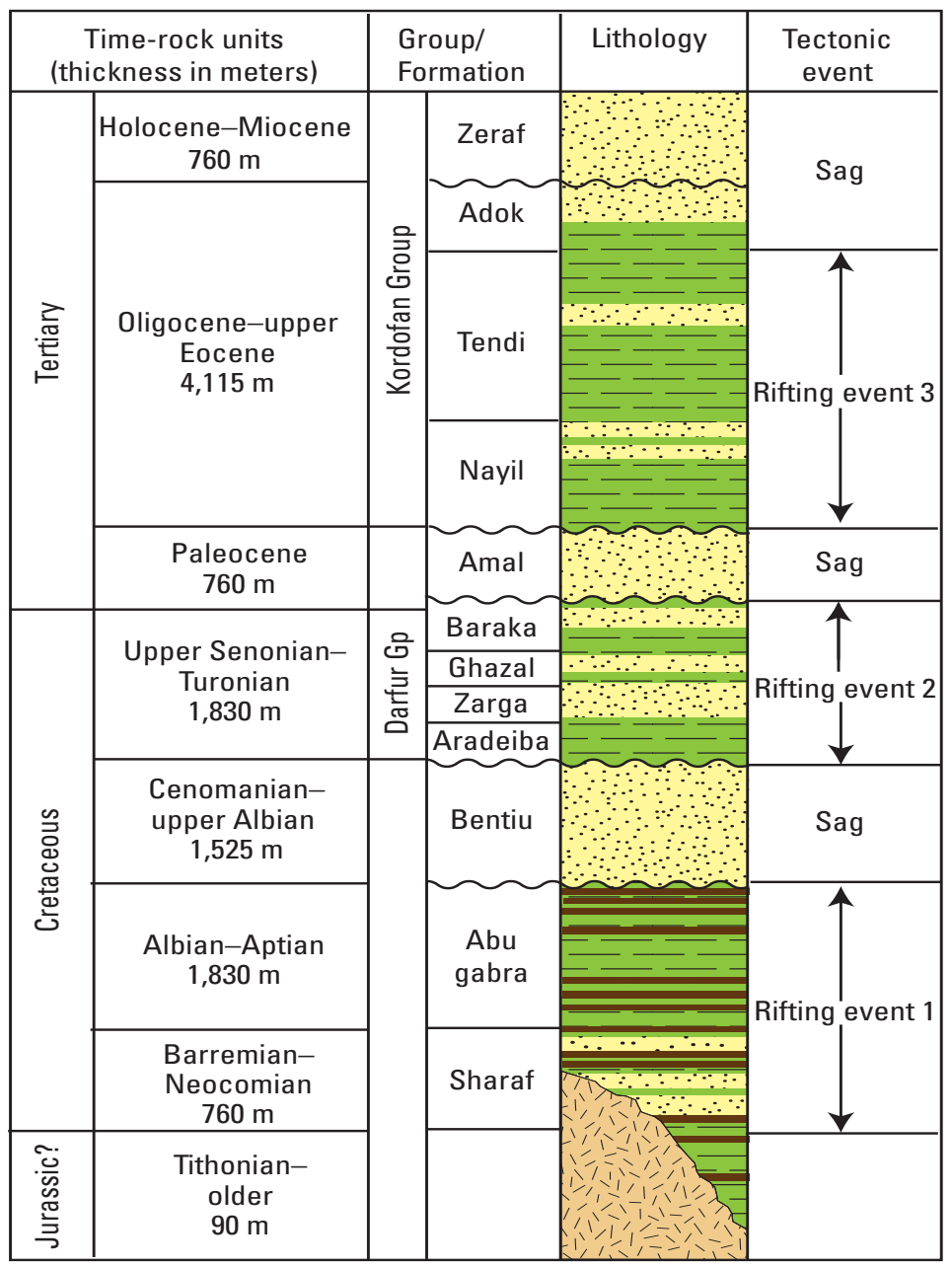

Melut Basin

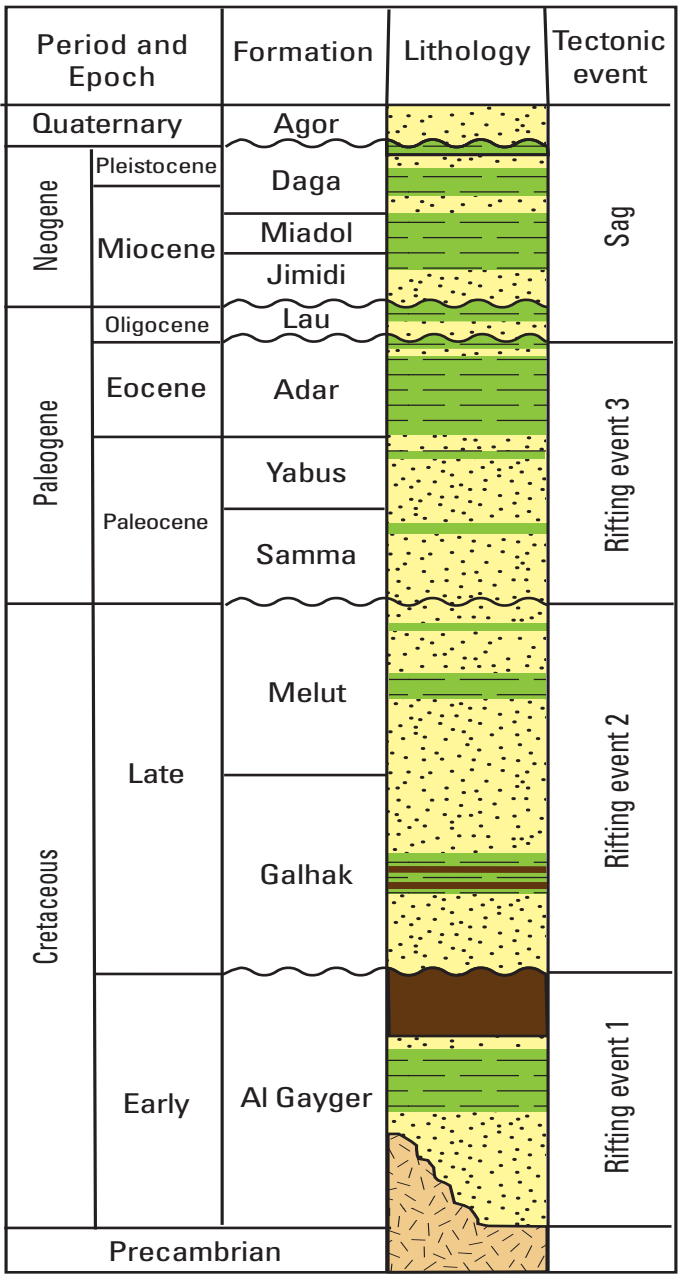

EXPLANATION

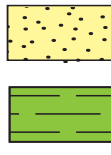

Sandstone and siltstone

Clay and shale, minor Type I

and Type III source rocks present

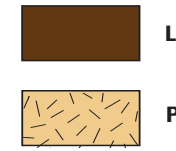

Lacustrine source rock

Precambrian basement

Figure 3. Generalized stratigraphic columns for the Muglad and Melut Basins, southern Sudan (see fig. 1). Modified after Mohamed and others (2000) and Dou and others (2007).

Table 1. Sud Province and Central African Rifts Assessment Unit results for undiscovered, technically recoverable oil, gas, and natural gas liquids.

[Largest expected mean field size in million barrels of oil and billion cubic feet of gas; MMBO, million barrels of oil. BCFG, billion cubic feet of gas. MMBNGL, million barrels of natural gas liquids. Results shown are fully risked estimates. For gas accumulations, all liquids are included as natural gas liquids (NGL). Undiscovered gas resources are the sum of nonassociated and associated gas. F95 represents a 95 percent chance of at least the amount tabulated; other fractiles are defined similarly. AU, assessment unit; $\mathrm{AU}$ probability is the chance of at least one accumulation of minimum size within the AU. NGL, natural gas liquids. Gray shading indicates not applicable]

\begin{tabular}{|c|c|c|c|c|c|c|c|c|c|c|c|c|c|c|}
\hline \multirow{3}{*}{$\begin{array}{l}\text { Province, Total Petroleum } \\
\text { Systems (TPS) and } \\
\text { Assessment Units (AU) }\end{array}$} & \multirow{3}{*}{$\begin{array}{l}\text { Field } \\
\text { type }\end{array}$} & \multirow{3}{*}{$\begin{array}{l}\text { Largest } \\
\text { expected } \\
\text { mean } \\
\text { field size }\end{array}$} & \multicolumn{12}{|c|}{ Total undiscovered resources } \\
\hline & & & \multicolumn{4}{|c|}{ Oil (MMBO) } & \multicolumn{4}{|c|}{ Gas (BCFG) } & \multicolumn{4}{|c|}{ NGL (MMBNGL) } \\
\hline & & & F95 & F50 & F5 & Mean & F95 & F50 & F5 & Mean & F95 & F50 & F5 & Mean \\
\hline \multicolumn{15}{|c|}{ Sud Province-Cretaceous-Cenozoic Composite TPS } \\
\hline \multirow{2}{*}{ Central African Rifts AU } & Oil & 1,112 & 3,141 & 6,809 & 13,222 & 7,310 & 531 & 1,321 & 3,169 & 1,522 & 14 & 35 & 87 & 41 \\
\hline & Gas & 3,677 & & & & & 2,824 & 9,822 & 26,776 & 11,696 & 73 & 259 & 732 & 312 \\
\hline $\begin{array}{l}\text { Total conventional } \\
\text { resources }\end{array}$ & & & 3,141 & 6,809 & 13,222 & 7,310 & 3,355 & 11,143 & 29,915 & 13,418 & 87 & 294 & 819 & 353 \\
\hline
\end{tabular}



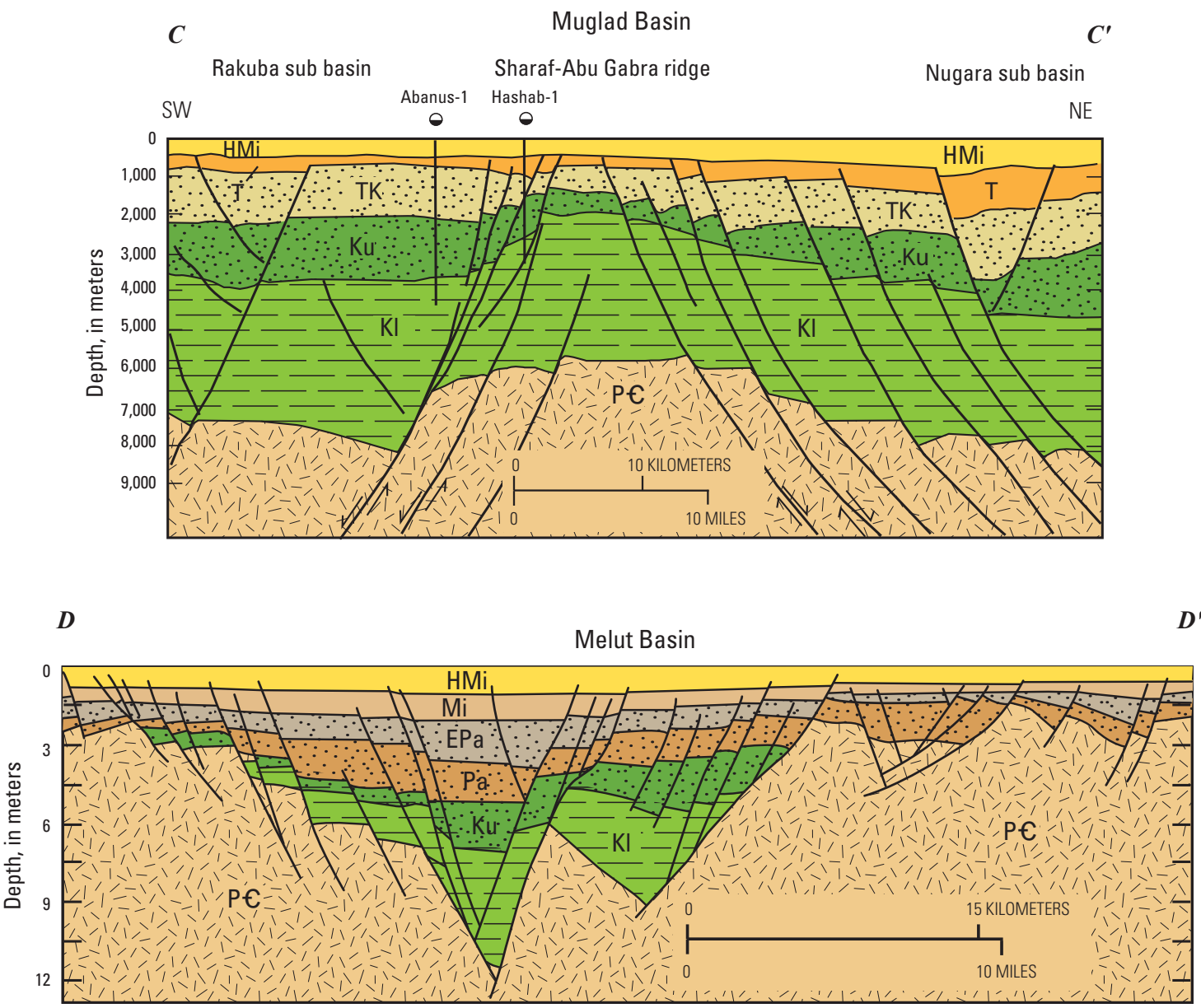

Figure 4. Schematic geologic cross sections of the Muglad and Melut Basins showing sedimentary fill in the southern Sudan. Location of cross sections shown in figure 1. P€, Precambrian; KI, Lower Cretaceous; Ku, Upper Cretaceous; T, Tertiary; TK, Tertiary to Upper Cretaceous; Pa, Paleocene; EPa, Eocene to Paleocene; Mi, Miocene; HMi, Holocene to Miocene. Modified after Mohamed and others (2002) and Dou and others (2007).

\section{For Additional Information}

Assessment results are available at the USGS Central Energy Resources Science Center Web site: http://energy.cr.usgs.gov/ oilgas/noga/ or contact Michael E. Brownfield, the assessing geologist (mbrownfield@usgs.gov).

\section{Sud Basin Province Assessment Team}

Michael E. Brownfield, Timothy R. Klett, Christopher J. Schenk, Ronald R. Charpentier, Troy A. Cook, Richard M. Pollastro, and Marilyn E. Tennyson.

\section{References Cited}

Dou, L., Xiao, K., Cheng, D., Shi, B., and Li, Z., 2007, Petroleum geology of the Melut Basin and the Great Palogue field, Sudan: Marine and Petroleum Geology, v. 24, no. 3, p. 129-144.
Genik, G.J., 1992, Regional framework, structural and petroleum aspects of rift basins in Niger, Chad and the Central African Republic (C.A.R.): Tectonophysics, v. 213, no. 1, p. $169-185$.

Genik, G.J., 1993, Petroleum geology of the Cretaceous-Tertiary rift basins in Niger, Chad, and Central African Republic: American Association of Petroleum Geologists Bulletin, v. 73, no. 8, p. $153-168$.

Mohamed, A.Y., Iliffe, J.E., Ashcroft, W.A., and Whiteman, A.J., 2000, Burial and maturation history of the Heglig field area, Muglad Basin, Sudan: Journal of Petroleum Geology, v. 23, no. 1, p. 107-128.

Mohamed, A.Y., Pearson, M.J., Ashcroft, W.A., and Whiteman, A.J., 2002, Petroleum maturation modeling, Abu Gabra-Sharaf area, Muglad Basin, Sudan: Journal of African Earth Sciences, v. 35 , no. 2, p. 331-344. 